\title{
Fire blight plant protection efficacy trial with resistant apple cultivar 'Ladina'
}

\author{
Vanessa Reininger ${ }^{1} \cdot$ Anita Schöneberg ${ }^{1} \cdot$ Eduard Holliger $^{1}$
}

Received: 15 April 2020 / Accepted: 12 December 2020/ Published online: 16 June 2021

(c) The Author(s) 2021

\begin{abstract}
Fire blight is a devastating disease of apple, pear and quince caused by the Gram-negative bacterium Erwinia amylovora. As antibiotics are not allowed against fire blight in Switzerland, optimization of alternative plant protection strategies is required. In this context, fire blight tolerant cultivars become of higher importance to control the disease. A plant protection product efficacy trial against fire blight with the susceptible cultivar 'Gala Galaxy' and the tolerant cultivar 'Ladina' bred at Agroscope was set up at the Agroscope Steinobstzentrum Breitenhof in 2018. Four different treatment strategies, including an untreated control, were tested on both cultivars after inoculation with Erwinia amylovora. 'Ladina' showed less fire blight blossom cluster infection in untreated and treated plants compared to 'Gala Galaxy'. Blossom cluster infection rates following different plant protection treatments did not differ significantly from each other in 'Gala Galaxy' whereas they did in 'Ladina'.
\end{abstract}

Keywords Erwinia amylovora · Fire blight · 'Gala galaxy' · 'Ladina' · Tolerant apple cultivar · Plant protection strategies

\section{Introduction}

Fire blight is a devastating disease affecting pome fruit production. Erwinia amylovora is a Gram-negative bacterium causing fire blight within the Rosaceae family on crops such as apple, pear, and quince (Vanneste 2000; Van der Zwet et al. 2012). The first fire blight incidence in Switzerland was observed in 1989 around Lake Constance on Cotoneaster spp. (Duffy et al. 2005) with a peak in 2007/2008 and incidence declining ever since. Owing to its distribution in Switzerland, fire blight no longer meets the criteria for regulation as a quarantine organism (exception: protected zone in the canton of Valais). In 2018, the European and Mediterranean Plant Protection Organization (EPPO) recommended regulation of the bacterium as a regulated non-quarantine pest (RNQP) on known host plant products (Malus, Pyrus, Cydonia, Sorbus etc.). These plants must still be free from fire blight if they are intended for commercial

Vanessa Reininger

vanessa.reininger@agroscope.admin.ch

1 Müller-Thurgau Strasse 29, 8820 Agroscope, Wädenswil, Switzerland use (agricultural fruit production, ornamental plants). With the exception of the protected zone (canton of Valais), fire blight is no longer subject to notification or control obligations. However, fire blight will still be a major concern in pip-fruits production as it is one of the most devastating bacterial diseases. As no antibiotics have been allowed in pip-fruits production in Switzerland from 2016 on, effective alternative plant protection strategies against fire blight are needed as stated by Sundin et al. (2016). Up to date there is authorized products available showing partial efficacy only (Reininger et al. 2017a, b, c; Stockwell et al. 2010). In this context, also tolerant cultivars will become of more importance to apple production (Sundin et al. 2016; Kellerhals 2017; Kellerhals et al. 2017; Silvestri and Egger 2011). One of those fire blight tolerant cultivars is 'Ladina', a breed from the research institute Agroscope in Wädenswil, Switzerland (Kellerhals et al. 2014; Leumann et al. 2013).

The purpose of this study was to determine efficacy of several non-antibiotic plant protection agents against fire blight on apple trees of the cultivars 'Gala Galaxy' and 'Ladina' in an outdoor, enclosed field site. 


\section{Materials and methods}

\section{Experimental design}

The efficacy of several plant protection treatments using antagonists was tested on potted three-year old 'Gala Galaxy' and 'Ladina' trees on rootstock 'M9'. Trees were potted in 101 containers, placed into an enclosed field site with a black insect-proof mesh around $(1 \times 2 \mathrm{~mm})$ and a hail mesh on top. Trees were drip-irrigated as needed without fertilizer and looked vigorous throughout the experiment. A total of 288 potted trees were arranged in a randomized complete block design, with six replicate blocks including 36 trees per treatment (six experimental trees per block). Trees were spaced one by three meter. A seventh, untreated but inoculated 'Gala Galaxy' tree was placed in the middle of each block for the sole purpose of inoculation (see below) (Fig. 1). This tree was excluded from rating and sampling. In compliance with strict biosafety regulations, experiments in this enclosed field site are allowed to be inoculated with Erwinia amylovora.

\section{Pathogen inoculation}

Nearly at full bloom, the middle tree in each block was sprayed with $135 \mathrm{ml}$ of a $1 \times 10^{9} \mathrm{cfu} / \mathrm{ml}$ suspension of a
1:1:1 mixture of three strains of E. amylovora (Ea 66116, Ea 66035 and Ea L 610/03/2013) isolated from Malus. E. amylovora stains were grown on King's B media in Petri dishes for $48 \mathrm{~h}$ at $28^{\circ} \mathrm{C}$ in an incubator. Bacterial cells were washed off and diluted to the respective concentration using a $0.8 \% \mathrm{NaCl}$ solution. A bumblebee population big enough to pollinate our filed site was placed into the experimental site allowing pollination and inoculation of the non-inoculated trees and their newly opened flowers with Erwinia amylovora on the experimental trees. As flowers last for only a few days newly opened flowers continuously serve as new inoculum source. Inoculated trees showed no symptoms during flowering yet but when flower clusters were counted for disease incidence rating on May $25^{\text {th }}$ those inoculated trees were in bad condition.

\section{Treatments}

The dates of applications of treatments are listed in Table 1 and the treatments for the experiment are presented in Table 2. The plant protection products LMA and BlossomProtect ${ }^{\mathrm{TM}}$ used in this study are commercially available in Switzerland via Omya and Andermantt Biocontrol, respectively. Plant protection products were applied using a motorized backpack sprayer (Birchmeier Sprühtechnik AG, Stetten, Switzerland) applying approx. $150 \mathrm{ml}$ per tree (corresponds to 500 liters per hectare)
Fig. 1 Schematic illustration of our randomized complete block design showing six single replicates of Treatment I. Each of those blocks or single replicates includes an inoculated tree in the middle (illustrated in red) and six experimental trees (illustrated in green)

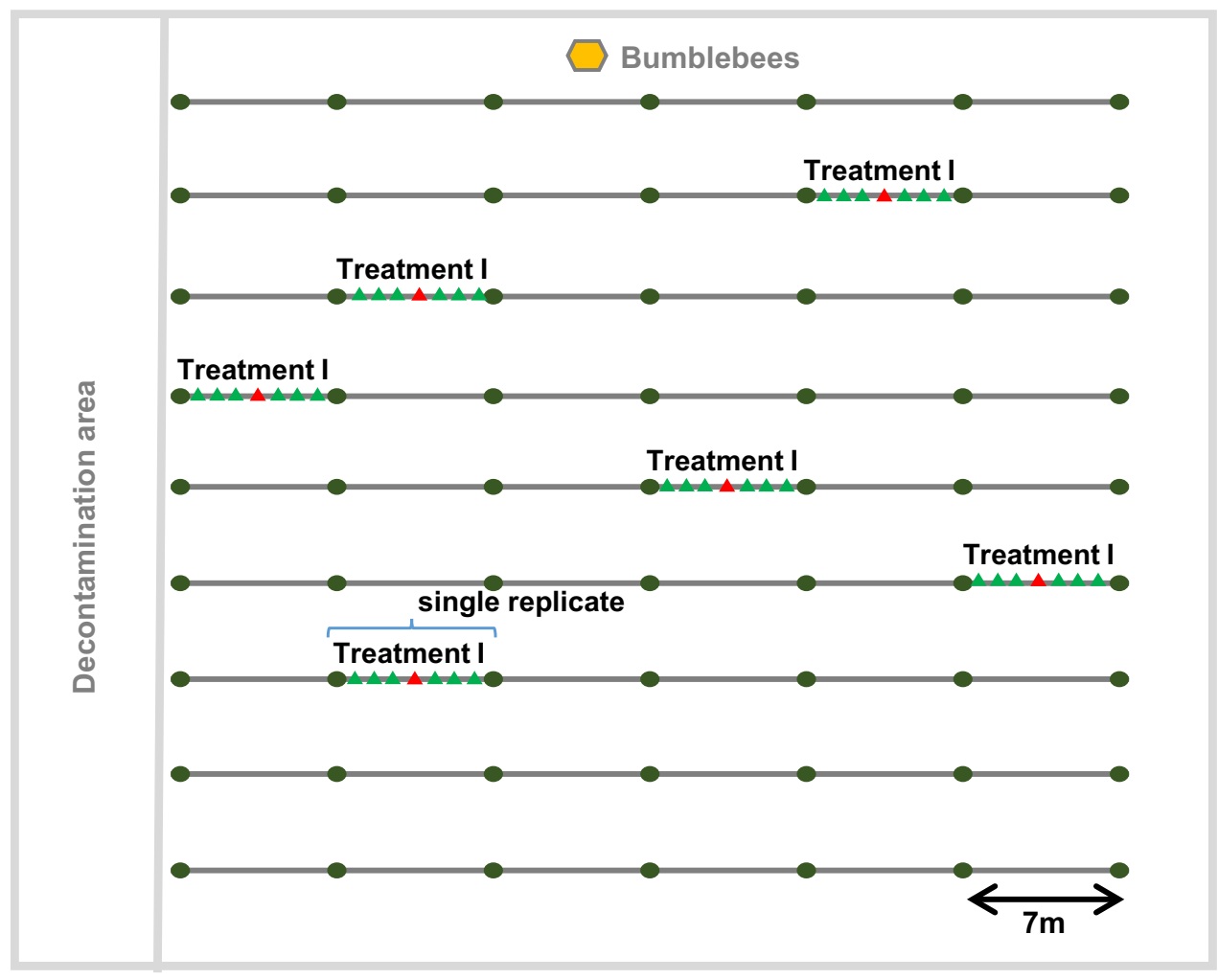

Black insect-proofed mesh 
Table 1 Treatment protocol for the fire blight efficacy experiment in 2018. Applications were conducted after sampling for cfu determination via real-time PCR. First treatment with antagonists took place already at the day of inoculation: Blossom Protect ${ }^{\text {TM }}$ and Pomavita (April $24^{\text {th }}$ )

\begin{tabular}{lllll}
\hline & Inoculation with E. amylovora & 1. Application & 2. Application & 3. Application \\
\hline Experiment I & April $24^{\text {th }}\left(1 \times 10^{9} \mathrm{cfu} / \mathrm{ml}\right)$ & April $25^{\text {th }}$ & April $27^{\text {th }}$ & April $29^{\text {th }}$ \\
\hline
\end{tabular}

and half of the recommended amount of plant protection product to account for small crown sizes in this field experiment. Inoculated middle trees were non-treated. The first application took place three hours after inoculation of trees with E. amylovora (Table 1). Control trees were not treated at all.

\section{Disease incidence rating}

Flower clusters were counted at the beginning of the experiment (full bloom) to get the total for each tree. About four and a half weeks after pathogen inoculation (May $25^{\text {th }}$ ), when fire blight symptoms were clearly visible, infected and healthy flower clusters were counted. On average 2600 flower clusters were counted per treatment for 'Gala Galaxy' and 1700 flower clusters for 'Ladina' (36 trees per treatment). Disease incidence and control efficacy according to Abbott (Abbott 1925) were calculated from means of each block (six trees per block) using the following formulas:

\section{i. Percent disease [\%]}

(Total number of flower clusters with fire blight symptoms / Total number of flower clusters at full bloom) $\times 100$

\section{ii. Control efficacy [\%] (according to Abbott(1925))}

((Percent disease on control tree - Percent disease on treated tree) / Percent disease on control) $\times 100$

Table 2 Treatments and their products with blossom cluster infection and efficacy data for the fire blight experiment 2018. Treatments were conducted three times after inoculation with $E$. amylovora (see Table 1). Different letters behind efficacy values indicate statistically

\section{Pathogen epidemiology on flowers}

Pathogen population dynamics on flowers during the experiment were investigated at four times after the inoculation using real-time PCR. The first sampling represents the baseline, i.e. the starting number of E. amylovora cells three hours post inoculation. The untreated control (T1 and T5) and the LMA strategy (T2 and T6) were sampled in both cultivars (see Table 2). Twenty-four flowers per sample ( 24 till $48 \mathrm{~h}$ old to already show a pathogen history, means not recently opened flowers) were harvested (petals removed) from twelve replicate trees receiving the same treatment and stored at $4{ }^{\circ} \mathrm{C}$ until further processing the next morning. Per flower $1 \mathrm{ml}$ PBS was added and flowers were put into an ultrasonic water bath for 4 min to transfer cells into the liquid.

For real-time PCR analysis, DNA was extracted using the BioSprint 96 DNA Plant Kit (Qiagen, Hilden, Germany) on a BioSprint 96 workstation (Qiagen, Hilden, Germany). Samples were prepared as follows: $1.5 \mathrm{ml}-$ Eppendorf tubes containing $500 \mu \mathrm{l}$ sample were centrifuged at 9,900 $\mathrm{g}$ for $11 \mathrm{~min}$ and the supernatant was discarded. The pellet was re-suspended in $300 \mu \mathrm{l}$ RTL buffer (lysis buffer) and vortexed for 20-30 seconds. Tubes were put into an incubator-shaker at $65^{\circ} \mathrm{C}$ at $1,000 \mathrm{rpm}$ for 30 min and subsequently centrifuged at $6,000 \mathrm{~g}$ for $5 \mathrm{~min}$. The BioSprint 96 was loaded according to the manufacturer's protocol using $100 \mu$ l elution buffer instead of $200 \mu \mathrm{l}$ and 'BS96 DNA Plant' was chosen as extracting program.

significant differences due to the treatments according to Tukey's HSD $(p \leq 0.05) . *$ Amount of product for three-year-old potted trees per hectare. ** This amount corresponds to the active ingredient

\begin{tabular}{|c|c|c|c|c|c|c|}
\hline ID & Cultivar & Product & Active ingredient & Amount of Product* & $\begin{array}{l}\text { Blossom cluster } \\
\text { infection }[\%]+/-\mathrm{SE}\end{array}$ & Efficacy $[\%]$ \\
\hline T 1 & Gala & Untreated Control & - & - & $14.3 \pm 1.3$ & \\
\hline T 2 & Gala & LMA & Potassium-aluminum-sulfate ( $80 \%)$ & $10 \mathrm{~kg}$ & $11.9 \pm 1.2$ & 16.9 (a) \\
\hline Т 3 & Gala & Blossom Protect $^{\mathrm{TM}}$ & Aureobasidium pullulans $\left(5 \times 10^{9} \mathrm{cfu} / \mathrm{g}\right)$ & $6 \mathrm{~kg}$ & $7.7 \pm 0.8$ & 46 (a) \\
\hline $\mathrm{T} 4$ & Gala & Pomavita & Pantoea agglomerans & $1.5 \mathrm{~g} / 6 \mathrm{~L} * *$ & $10.9 \pm 1.6$ & $22.6(a)$ \\
\hline T 5 & Ladina & Untreated Control & - & - & $6.4 \pm 1.1$ & \\
\hline Т 6 & Ladina & LMA & Potassium-aluminum-sulfate ( $80 \%)$ & $10 \mathrm{~kg}$ & $0.6 \pm 0.2$ & 94.8 (a) \\
\hline Т 7 & Ladina & Blossom Protect ${ }^{\mathrm{TM}}$ & Aureobasidium pullulans $\left(5 \times 10^{9} \mathrm{cfu} / \mathrm{g}\right)$ & $6 \mathrm{~kg}$ & $0.3 \pm 0.2$ & $97.8(a)$ \\
\hline T 8 & Ladina & Pomavita & Pantoea agglomerans & $1.5 \mathrm{~g} / 6 \mathrm{~L}^{* *}$ & $1.8 \pm 0.3$ & $87.3(b)$ \\
\hline
\end{tabular}


The ams $\mathrm{C}$ gene, which is involved in the synthesis of the polysaccharide amylovoran, is supposed to be unique to $E$. amylovora (Bugert and Geider 1995; Bereswill et al. 1995). Thus, we used those very specific Ams primers developed by Pirc et al. (2009) for our real-time PCR analysis (Table 3). Each reaction contained $20 \mu \mathrm{l}$ composed as follows: $2 \mu \mathrm{l}$ $\mathrm{ddH}_{2} \mathrm{O}, 10 \mu \mathrm{T}$ TaqMan ${ }^{\circledR}$ Environmental Master mix 2.0 (Applied Biosystems by life technologies, Warrington, UK), $1.8 \mu \mathrm{l}$ primer Ams 116F and Ams 189R each $(10 \mu \mathrm{M})$ (Sigma-Aldrich, Buchs, Switzerland), $0.4 \mu \mathrm{l}$ TaqMan ${ }^{\circledR}$ probe Ams 141T (10 $\mu$ M) (Sigma-Aldrich, Buchs, Switzerland) and $4 \mu \mathrm{LNA}$. Universal cycling conditions were used [2 min at $50^{\circ} \mathrm{C}, 10 \mathrm{~min}$ at $95^{\circ} \mathrm{C}$ followed by 45 cycles of $15 \mathrm{~s}$ at $95^{\circ} \mathrm{C}$ and $1 \mathrm{~min}$ at $60^{\circ} \mathrm{C}$ ] and samples run in duplicates on a ViiA ${ }^{\mathrm{TM}} 7$ Real-time PCR machine (Applied Biosystems, Carlsbad, USA). A standard curve with known amounts of DNA run on each plate in triplicates to quantify DNA in our samples. Mean amplification efficiency of real-time PCR was $95 \%$.

\section{Statistical analysis}

Statistically significant differences were calculated running a linear mixed effects model (lme) using sqrt-transformed or non-transformed data for every single tree, followed by a
Table 3 Primer and TaqMan ${ }^{\circledR}$ probe for real-time PCR amplification of the amsC gene in E. amylovora (Pirc et al. 2009)

\begin{tabular}{lll}
\hline Name & Sequence $\left(\mathbf{5}^{\boldsymbol{}} \mathbf{-} \mathbf{3}^{\boldsymbol{}}\right)$ & Amplicon length \\
\hline Ams 116F & TCC CAC ATA CTG TGA ATC & 74 bp \\
& ATC CA & \\
Ams 189R & GGG TAT TTG CGC TAA TTT & \\
& TAT TCG \\
Ams 141T & FAM-CCA GAA TCT GGC CCG \\
& CGT ATA CCG-TAMRA & \\
\hline
\end{tabular}

Tukey's HSD Test for pairwise comparisons between treatments in the statistics software R (R Core Team 2014). In the lme model, efficacy was tested in dependence of block treatment and cultivar. For real-time PCR data a pairwise t-test was run for each sampling day.

\section{Results}

\section{Disease incidence}

Experimental conditions in April/May 2018 at the Agroscope experimental fire blight field site in Wintersingen, BL were conductive for E. amylovora infection (Fig. 2). Blossom cluster infection in the untreated 'Gala Galaxy' control

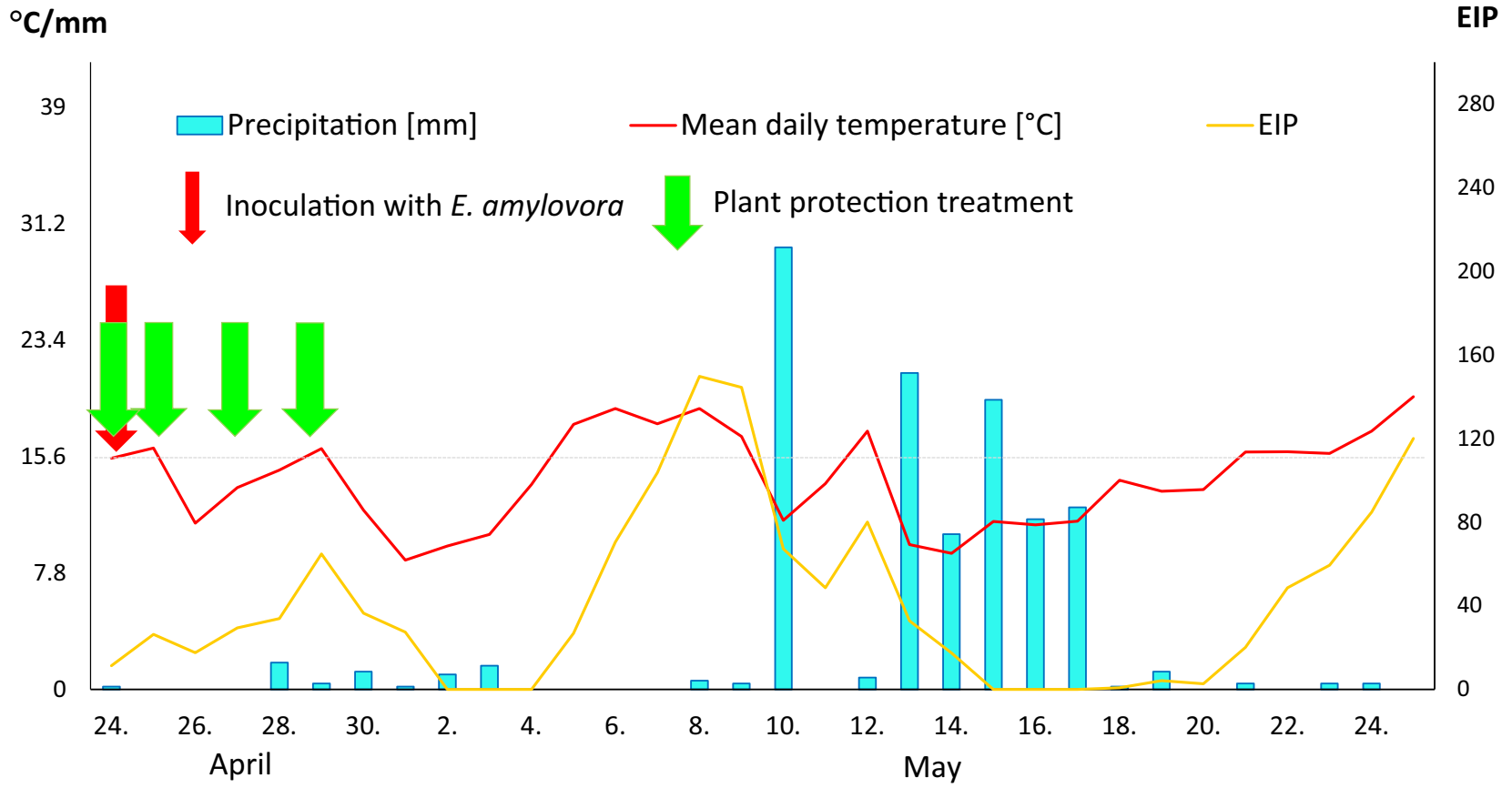

Fig. 2 Weather conditions and EIP-values (Epiphytic Infection Potential) during the experiment in 2018 in Wintersingen, Switzerland. The Maryblyt prediction model was used and the EIP-value threshold predicting an infection event was set to 110 . No infection days were predicted for the experiment. Timing of artificial inoculation of the middle trees with E. amylovora is symbolized by the red arrow; green arrows symbolize timing of post-inoculation treatments with plant protection products. Antagonists were applied the first time at the day of inoculation 
Fig. 3 Boxplots showing disease incidence [\%] in both cultivars 'Gala Galaxy' and 'Ladina' according to different plant protection treatments. Each box consists of 36 single trees, therefore those boxplots represent raw data. Efficacy values were calculated according to Abbott. Infestations correspondss to blossom cluster infection. The boxplots are drawn according to Crawley (2007): The bold horizontal line shows the median. The bottom and top of the box show the $25^{\text {th }}$ and $75^{\text {th }}$ percentiles, respectively. The vertical dashed lines ('whiskers') show either the maximum value or 1.5 times the interquartile range of the data, whichever is the smaller

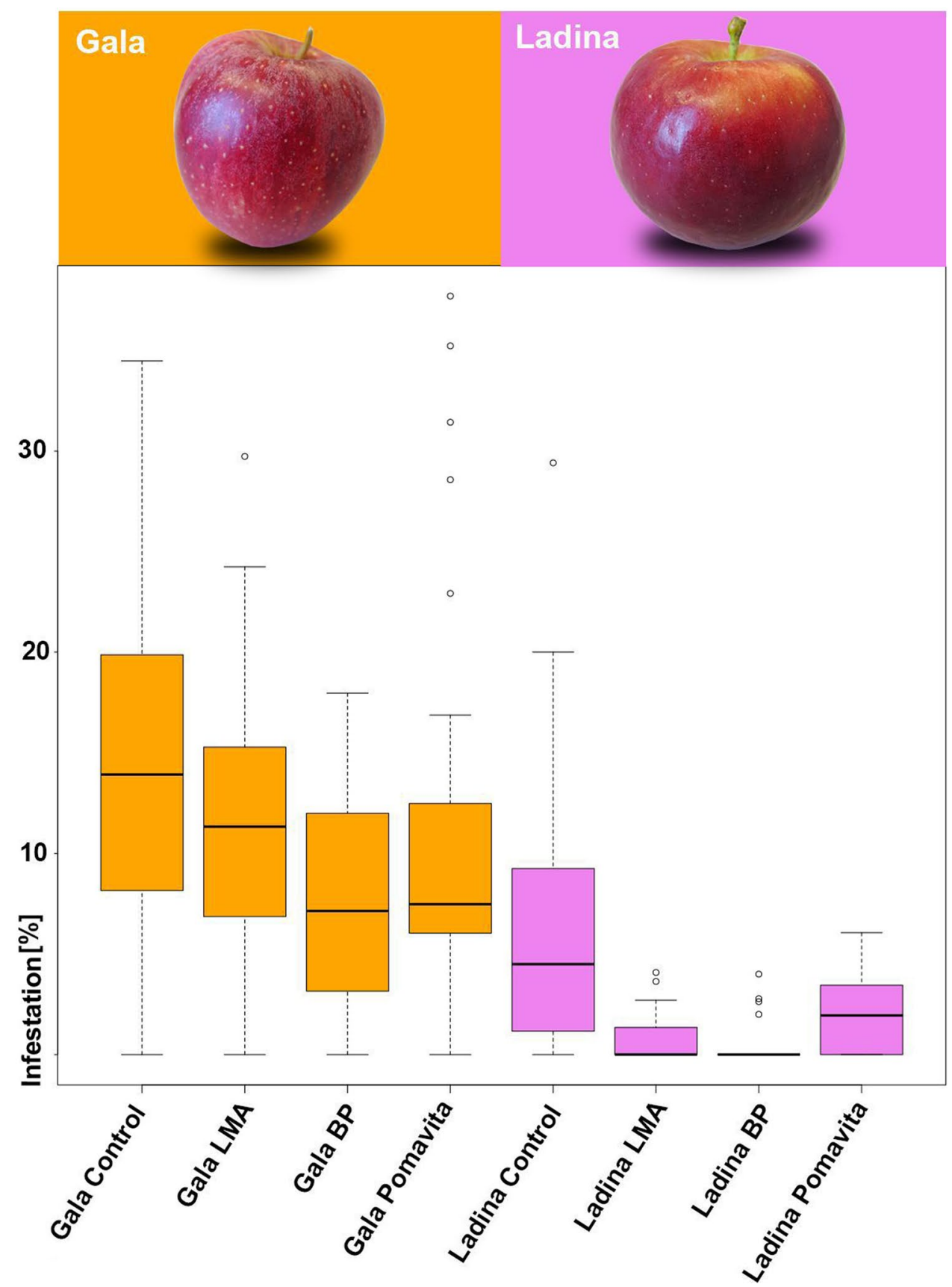

was $14.3 \%$ whereas it was $6.4 \%$ in 'Ladina (see Table 2 and Fig. 3). The European and Mediterranean Plant Protection Organization (EPPO) standard 1/166(3) blossom cluster infection rates (min. 5\% fire blight blossom cluster infection in the untreated control) were met in this experiment for both cultivars (Bulletin 2013). Fire blight blossom cluster infection in treatments with plant protection products was significantly lower compared to the control both in 'Gala Galaxy' ( $\mathrm{p}<0.001)$ and in 'Ladina ( $\mathrm{p}<0.001)$. There were no significant differences in terms of efficacy between treatments in 'Gala Galaxy' but for 'Ladina', as the antagonist product Pomavita showed a significantly lower efficacy than LMA and Blossom Protect ${ }^{\text {TM }}$. Efficacy values for 'Ladina' were relatively high ranging from $87.3 \%$ to $97.8 \%$ compared to a maximum of $46 \%$ in 'Gala Galaxy' (Table 2 and Fig. 3). The most effective plant protection product for both cultivars was Blossom Protect ${ }^{\mathrm{TM}}$. Due to natural experimental conditions, variation between replicates was high, especially for lower efficacy values, resulting in a rather high variance. 

ogy on flowers according to real-time PCR analysis. The boxplots are drawn according to Crawley (2007): The bold horizontal line shows the median. The bottom and top of the box show the $25^{\text {th }}$ and $75^{\text {th }}$ percentiles, respectively. The vertical dashed lines ('whiskers') show either the maximum value or 1.5 times the interquartile range of the data, whichever is the trol on 'Gala Galaxy', lavender = LMA on 'Gala Galaxy', pink $=$ untreated control on 'Ladina' and rose = LMA on 'Ladina'
Fig. 4 Pathogen epidemiolsmaller. Blue = untreated con-

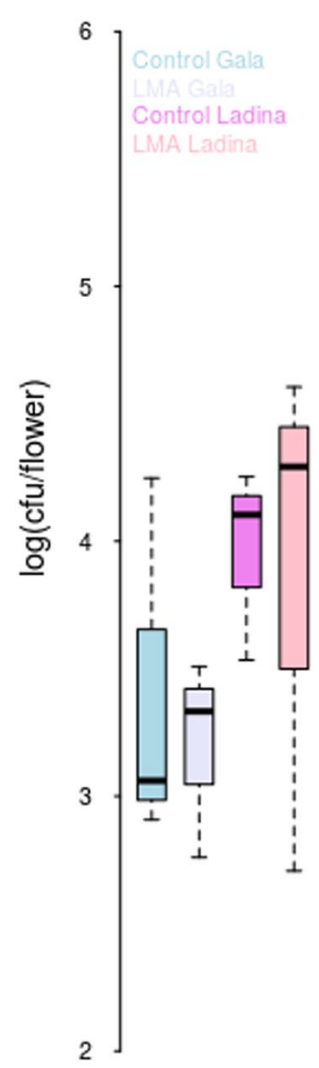

April 24
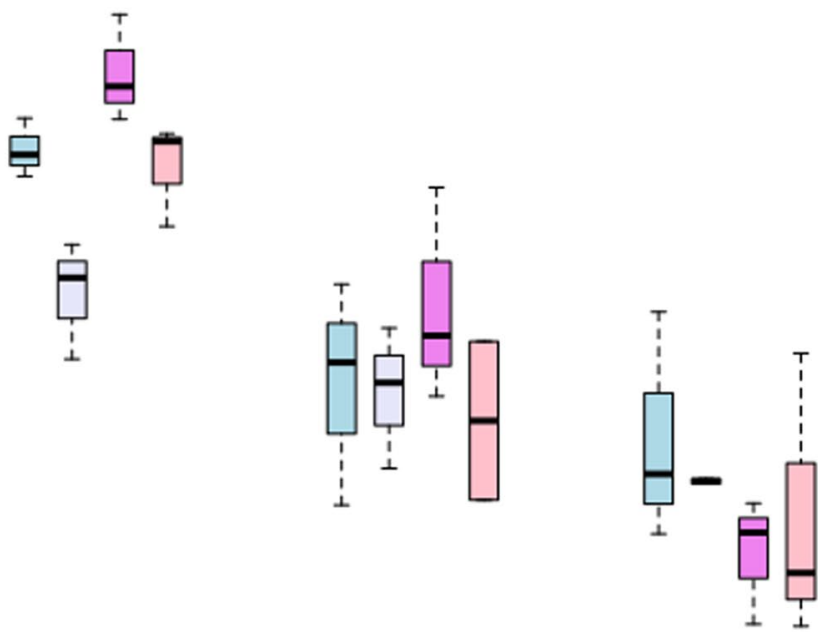

\section{Pathogen epidemiology on flowers}

Baseline values on April $24^{\text {th }}$ were not homogenous due to high variation between replicates, even though no plant protection treatment took place yet but three hours after center trees were inoculated with the pathogen mixture. Cell numbers increased after inoculation and control trees had higher cell numbers than LMA treated trees. 'Ladina' showed higher cell numbers than 'Gala Galaxy' except for the last day of sampling (Fig. 4). In general, cell numbers went up at the second sampling day to drop again thereafter. Only one significant difference in pairwise comparisons could be detected on day two between the control and LMA treatment in 'Gala Galaxy' $(\mathrm{p}=0.019)$.

\section{Discussion}

Even though inoculum density of Erwinia amylovora was very high, but still comparable with other studies using lower cell loads in combination with direct inoculation of blossoms (Pusey et al. 2011; Reininger et al. 2017a, b, c), blossom cluster infection values were in a reasonable and comparable range. Experimental conditions were favorable for fire blight development but temperatures were not extremely high which allowed for a natural setup. No infection day, which means an EIP above 110, was observed during treatment and sampling of apple blossoms, but thereafter (see Fig. 2).

As outlined before, new methods for fire blight management are needed (Sundin et al. 2016) and therefore the integration of fire blight resistant cultivars seems to be a promising and important approach (Kellerhals et al. 2017; Leumann et al. 2013). We combined the highly susceptible cultivar 'Gala Galaxy' and the resistant cultivar 'Ladina' with antagonistic and conventional fire blight treatments. 'Ladina' showed less blossom cluster infection in the untreated control even though inoculum density was the same for both cultivars.

In terms of treatments, we found lower cell loads on treated plants and accordingly less blossom cluster infection compared to the control, regarded for each cultivar separately. This observation of less blossom cluster infection having lower amounts of cells per blossom has been confirmed before (Hinze et al. 2016). But on the other hand, we found more cells in 'Ladina' compared to 'Gala Galaxy' even though blossom cluster infection was lower in 'Ladina'. This fact might be due to a possible mechanism in 'Ladina' where blossoms will be separated from the plant or dropped prior to infection. While evaluating blossom cluster infection we found blossoms which seemed to be infected 
but were dropped by the tree. BlossomProtect ${ }^{\mathrm{TM}}$ containing the yeast Aureobasidium pullulans and Pomavita the bacterium Pantoea agglomerans showed the same efficacy on 'Gala Galaxy'. On the contrary, BlossomProtect ${ }^{\mathrm{TM}}$ showed significantly higher efficacy on 'Ladina' in comparison to the antagonistic bacterium Pantoea agglomerans being the active ingredient in Pomavita. This might be due to high variation of efficacy in 'Gala Galaxy'. Antagonists might be carried over by bumblebees to other blossoms as other plant protection products as well. In our case the yeast or bacterial antagonistic cell load was not evaluated in the other treatments but as blossom cluster infections were highest in control plants compared to other treatments, this effect could not have been very strong if at all (Fig. 3). Additionally, the entire experiment would have been effected the same way as all trees were placed into the same containment.

In general, efficacy in 'Ladina' showed little variation and very high values. Therefore, the combination of a resistant apple cultivar with plant protection treatments seems to be a promising strategy, which needs to be further tested.

Acknowledgements Our thank goes to all project partners of "Together against Fire Blight", namely the Federal Office for Agriculture (FOAG), Swissfruit and the Canton of Aargau for their funding. Additionally, we would like to thank all project partners of the project HERAKLES Plus for funding: the CAVO Foundation, IP-SUISSE, the cantons of Aargau, Berne, Lucerne, St. Gallen, Thurgau and Zurich.

\section{Funding Open Access funding provided by Agroscope}

Open Access This article is licensed under a Creative Commons Attribution 4.0 International License, which permits use, sharing, adaptation, distribution and reproduction in any medium or format, as long as you give appropriate credit to the original author(s) and the source, provide a link to the Creative Commons licence, and indicate if changes were made. The images or other third party material in this article are included in the article's Creative Commons licence, unless indicated otherwise in a credit line to the material. If material is not included in the article's Creative Commons licence and your intended use is not permitted by statutory regulation or exceeds the permitted use, you will need to obtain permission directly from the copyright holder. To view a copy of this licence, visit http://creativecommons.org/licenses/by/4.0/.

\section{References}

Abbott WS (1925) A method of computing the effectiveness of an insecticide. J Am Mosq Control Assoc 3:302-3

Bereswill S, Bugert P, Bruchmuller I, Geider K (1995) "Identification of the fire blight pathogen, Erwinia amylovora, by PCR assays with chromosomal DNA", Applied. Environmental Microbiology 61:2636-42

Bugert P, Geider K (1995) Molecular analysis of the ams operon required for exopolysaccharide synthesis of Erwinia amylovora. Mol Microbiol 15:917-33
Bulletin OEPP/EPPO (2013) Erwinia amylovora. Bulletin OEPP 43(375): 21

Crawley MJ (2007) The R book. Wiley, Chichester, England

Duffy B, Schaerer HJ, Buenter M, Klay A, Holliger E (2005) Regulatory measures against Erwinia amylovora in Switzerland. Bulletin OEPP 35:239-44

Hinze M, Kohl L, Kunz S, Weisshaupt S, Ernst M, Schmid A, Voegele RT (2016) Real-time PCR detection of Erwinia amylovora on blossoms correlates with subsequent fire blight incidence. Plant Pathology 65:462-69

Kellerhals M (2017) 'Advances in pest- and disease-resistant apple varieties.' in K. Evans (ed.), Achieving Sustainable Cultivation of Apples (Burleigh Dodds Science Publishing Ltd: Sawston).

Kellerhals M, Baumgartner IO, Leumann L, Lussi L, Schutz S, Patocchi A (2014) 'Breeding High Quality Apples with Fire Blight Resistance.' in F. Rezzonico, T. H. M. Smits and E. Holliger (eds.), Xiii International Workshop on Fire Blight (Int Soc Horticultural Science: Leuven 1).

Kellerhals M, Schutz S, Patocchi A (2017) BREEDING FOR HOST RESISTANCE TO FIRE BLIGHT. J Plant Pathol 99:37-43

Leumann L, Baumgartner I, Lussi L, Frey L, Nölly M, Kellerhals M (2013) Ladina, die neue feuerbrandrobuste Apfelsorte. Schweizer Zeitschrift für Obst- und Weinbau 1(13):10-13

Pirc M, Ravnikar M, Tomlinson J, Dreo T (2009) Improved fireblight diagnostics using quantitative real-time PCR detection of Erwinia amylovora chromosomal DNA. Plant Pathology 58:872-81

Pusey PL, Stockwell VO, Reardon CL, Smits TH, Duffy B (2011) Antibiosis activity of Pantoea agglomerans biocontrol strain E325 against Erwinia amylovora on apple flower stigmas. Phytopathology 101:1234-41

Reininger V, Schöneberg A, Walch B, Holliger E (2017a) 'Feuerbrand - Pflanzenschutzmittelversuch 2017', Schweizer Zeitschrift für Obst- und Weinbau: 8-11.

Reininger V, Schöneberg A, Holliger E (2017b) Pant Protection Field Trials against Fire Blight in Switzerland in 2015. J Plant Pathol 99:131-36

Reininger V, Schöneberg A, Perren S, Holliger E (2017c) 'Feuerbrand: Pflanzenschutzmittelversuche 2016', Schweizer Zeitschrift für Obst- und Weinbau: 4-7.

Silvestri G, Egger S (2011) Robust varieties crucial for fireblight control. Agrarforschung Schweiz 2:526-33

Stockwell VO, Johnson KB, Sugar D, Loper JE (2010) Control of fire blight by Pseudomonas fluorescens A506 and Pantoea vagans C9-1 applied as single strains and mixed inocula. Phytopathology 100:1330-9

Sundin GW, Castiblanco LF, Yuan XC, Zeng Q, Yang CH (2016) Bacterial disease management: challenges, experience, innovation and future prospects. Mol Plant Pathol 17:1506-18

Team RC (2014) "R: A language and environment for statistical computing." In. Vienna, Austria: R Foundation for Statistical Computing.

Van der Zwet T, Orolaza-Halbrendt N, Zeller W (2012) Fire Blight (The American Phytopathological Society).

Vanneste JL (2000) What is fire blight? Who is Erwinia amylovora? How to control it? Wallingford, Cabi Publishing-C a B Int

Publisher's Note Springer Nature remains neutral with regard to jurisdictional claims in published maps and institutional affiliations. 